\title{
Architectural Responsiveness of Entry Threshold Spaces of Public Buildings: Physical Attributes and People's Perceptions
}

\author{
D. Ironi Padmaperuma, \\ Ubesingha a Buddhinie, \& Jeewanthi Senadeera \\ City School of Architecture, Colombo, Sri Lanka. \\ Corresponding Author: D. Ironi Padmaperuma; E-mail- ironisbv@gmail.com
}

\begin{abstract}
Entry Threshold Spaces of public buildings serve as transitional spaces from the outer world to the inner space. Therefore, they play a vital role in making buildings well perceived by people. Poorly designed entry threshold spaces of buildings often misguide the public. Therefore, this paper aimed to explore how to design Entry Threshold Spaces of public buildings in an architecturally responsive manner that can be perceived well by the people. The literature survey carried out identified five physical attributes of responsive architecture and components of each physical attribute. Mixed mode research approach was employed to explore the architectural responsiveness and to identify the people's perception of Entry Threshold Spaces of three selected cases. Data was collected via interviews, document reviews, and observations and through a questionnaire; and were analyzed within case and cross case wise. The paper reveals that height-width ratio and human scale of Entry Threshold Spaces contribute least to people's perception of public buildings. Facade details, materials used, signs, symbols, etc. that contribute to the richness of the experience are well perceived by the people. Further, this paper finds that the Entry Threshold Spaces of public buildings are well perceived by the people despite their poor responsiveness to physical attributes of Architecture.
\end{abstract}

Keywords: threshold space, entrance, spatial progression, architectural responsiveness, people perception

\section{Introduction}

Entry Threshold Spaces (ETS) of buildings are the keystones for external and internal spaces (Dudzinski, 2018) as they act as transitional spaces from the outer world to the inner spaces (Dudzinski, 2019). Further, they are capable of linking or separating two heterogeneous realms. Being the starting point of a spatial sequence, an ETS is designed to provide the ultimate spatial experience, while adopting the user to a transitional encounter. It is the most memorable of its fragment, as it is the first impression in the meeting with the building (Włodarczyk, 1992). According to Alexander (1977), buildings with a graceful transition between the street and the inside, are more tranquil than those that open directly to the street. They provide the users a motivation to explore, while enhancing the spatial experience throughout, until one reaches the building. Public buildings intend to serve the mass population, therefore they should be designed in a manner that can be well addressed by the public. Therefore, they should be perceived well by people. Poorly designed ETS of public buildings often misguide them. Therefore, the objective of this paper is to explore how to design ETS of public buildings in an architecturally responsive manner that can be well perceived by people. 


\section{Literature Review}

\section{Components of an Entry Threshold Space (ETS)}

The way of our development can be conceived as the perceptual string that joins the spaces of a building, or any arrangement of insides or outside spaces, together (Ching, 2015; Fontana, et al.,2016; Norberg-Schulz, 1979)

As one moves through a spatial sequence, the experience of a specific space relates to the previously experienced and future anticipated spaces. Components of an ETS are considered positive elements that affect one's perception of forms and spaces of a building (Ching, 2015).

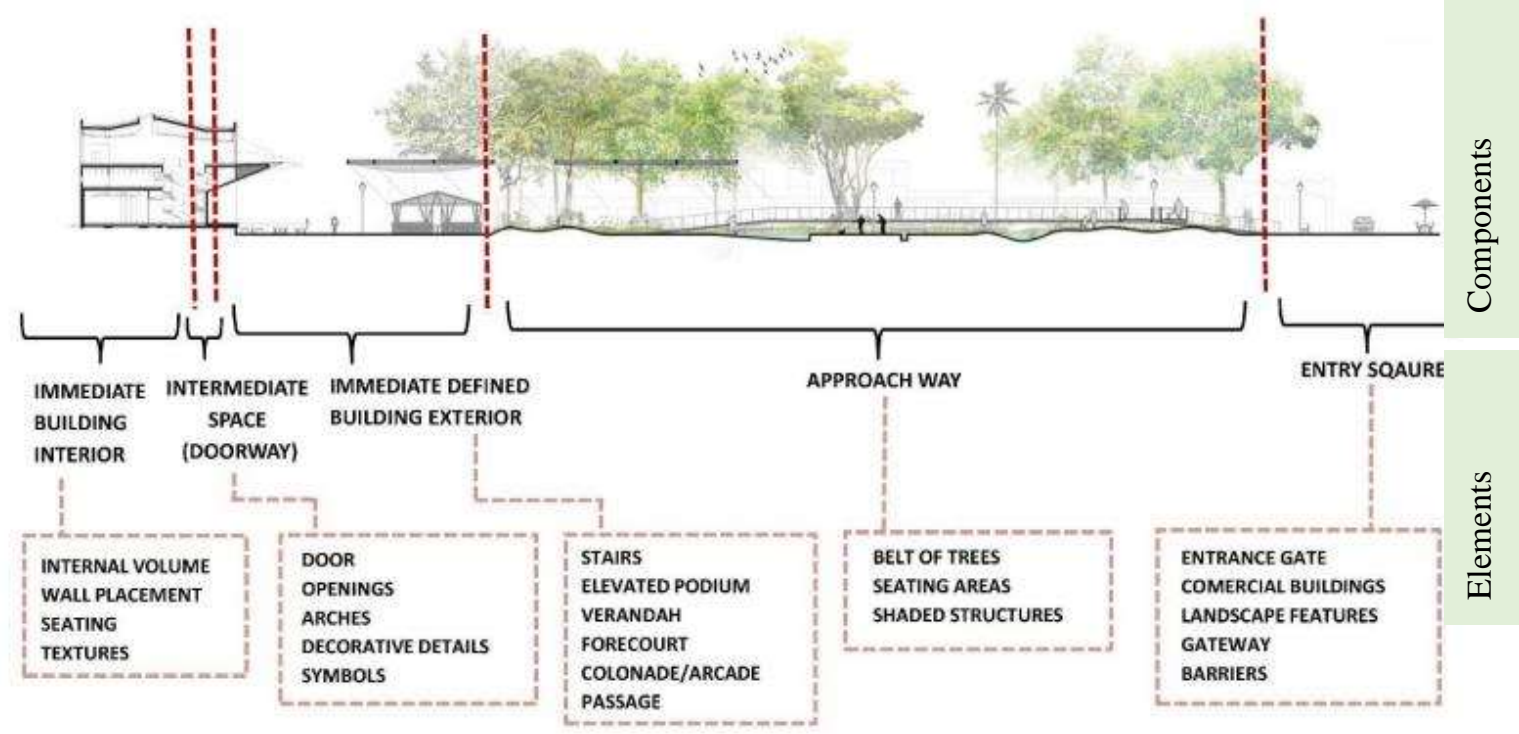

Fig. 1: Components of an entry threshold space and the elements of them Source: adopted from (Ching, 2015; Fontana, 2016; Norberg-Schulz, 1979)

Fig. 1 illustrates the primary components of an ETS. They are: Entry square, Approach way, Immediate defined building exterior space, Intermediate space: doorway, and Immediate building interior space (Ching, 2015; Fontana, 2016; Norberg-Schulz, 1979)

Entry square: Entry squares are most often connected with city roads. These city roads or approach ways can be as congested, traffic prone and uncomfortable for users, so that they mislead them from the destination. Hence, it is necessary to treat the entry square appropriately.

Approach way: Approach way is an intermediate space positioned prior to entering the interior of a building which links the building with its surroundings and defines the access to the building (Norberg-Schulz, 1979).

Immediate defined building exterior space: This reflects the intermediate space between the approach way and the doorway. It is the immediate defined field of exterior space before entering to the main space. It acts as a transitional point within the ETS, which offers the feeling of entering a specific built form. This space can vary from building to building and their functionality.

Intermediate space (doorway): Many architectural elements, signs and symbols are used in designing entry doorways. The proportions of the doorway express a variety of meanings and values, which differs depending on the socio-cultural and economic contexts. Doorways create an entrance from one realm to another. 
Immediate building interior space: This is defined as the first interior space experienced upon entering. The main lobby space can be cited as an example.

\section{Architectural Responsiveness}

The responsiveness of the ETS to its context is a necessity. The term responsiveness is used in architecture in many ways and has been prevalent amongst most urban and socialconscious designers. As Hiller and Hanson (1989) states, responsiveness is the relationship between the social life and the arrangement of the built environment. On the other hand, Carr, S., Rivlin, L. \& Stone, A., (1993) Identify responsiveness as one of the basic aspects of a public space apart from the need to be meaningful and democratic. According to Bentley (1985), responsiveness is when the built environment provides its users with an essentially democratic setting, enriching their opportunities for interaction by maximizing the degree of choice available.

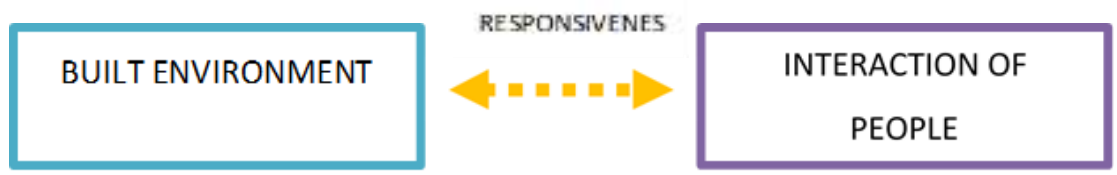

Fig. 2: Architectural responsiveness Source: Hiller and Hanson (1989)

Responsiveness of public spaces are vital to stimulate a myriad of public interactions and activities. Therefore, in order to understand the responsiveness of ETS, it is important to understand the physical attributes of architectural responsiveness.

\section{Physical Attributes of Responsive Architecture}

Responsiveness of public spaces can be achieved through simple physical alterations to a space (Whyte, 1980). Five physical attributes of architectural responsiveness were identified from literature. They are: physical permeability, human scale, climatic responsiveness, richness of experience and visual permeability (Bentley, 1985; Gehl, 2010; Hertzberger, 2008; Jacob, 1993; Lynch, 1960; Yavus, 2009; Whyte 1980). These are general physical attributes which can be applied for ETS. These attributes comprise of a variety of components which can be identified by many architectural elements. Refer Table 1.

\section{Physical Permeability}

As per Bentley (1985), physical permeability is a key measure of responsiveness in architecture, measured by the degree of choice allowed for people moving from one place to another. Components of physical permeability are: street edge treatment and punctuation (Clemente \& Erwing, 2013). While availability of shady green areas, secured pedestrian network, forecourt with seating arrangements encourage public movement of a street edge (Clemente and Erwing, 2013); gaps, hidden spaces, distances or breaks between two existences create punctuations; making urban pauses during spatial progression (Allsopp and Bruce, 1981).

\section{Human Scale}

Human scale refers to the organization of physical elements in relation to the scale and proportions of the human body; thus, it directly influences the human movement along the space (Jacobs, 1993). Height-to-width ratio, ETS with adequate walking space, immediate internal building volume, are important to achieve human scale of the ETS (Jacobs, 1993). 
Table 1: Physical Attributes of Architectural Responsiveness

\begin{tabular}{|c|c|c|c|}
\hline $\begin{array}{l}\text { Physical } \\
\text { Attributes of } \\
\text { Responsive } \\
\text { Architecture }\end{array}$ & $\begin{array}{l}\text { Component of } \\
\text { Physical Attributes }\end{array}$ & $\begin{array}{l}\text { Architectural Elements of } \\
\text { Components }\end{array}$ & References \\
\hline \multirow{2}{*}{$\begin{array}{l}\text { Physical } \\
\text { Permeability }\end{array}$} & $\begin{array}{l}\text { Street edge with } \\
\text { public movement }\end{array}$ & $\begin{array}{l}\text { Shady green areas, secured } \\
\text { pedestrian network, forecourt with } \\
\text { seating arrangements, encourage } \\
\text { public movement }\end{array}$ & $\begin{array}{l}\text { Clemente and Erwing, } \\
\text { (2013) }\end{array}$ \\
\hline & Punctuations & $\begin{array}{l}\text { Gaps, hidden spaces, distances or } \\
\text { breaks between two existences } \\
\text { create punctuations }\end{array}$ & Allsopp and Bruce (1981) \\
\hline \multirow{3}{*}{ Human-Scale } & $\begin{array}{l}\text { Height-to-width } \\
\text { (distance) ratio }\end{array}$ & $\begin{array}{l}\text { Distance from the building : height } \\
\text { of the building }=1: 2-3\end{array}$ & Jacobs (1993) \\
\hline & $\begin{array}{l}\text { Adequate walking } \\
\text { space }\end{array}$ & $\begin{array}{l}\text { Width of passageways, and ramps, } \\
\text { walkways, steps with adequate } \\
\text { space. }\end{array}$ & $\begin{array}{l}\text { Ariess (2009); Underhill } \\
\text { (1999) }\end{array}$ \\
\hline & $\begin{array}{l}\text { Large immediate } \\
\text { internal building } \\
\text { volume }\end{array}$ & Atriums and multiple height spaces & Gehl (2010) \\
\hline \multirow[b]{2}{*}{$\begin{array}{l}\text { Climate } \\
\text { Responsiveness }\end{array}$} & External shading & $\begin{array}{l}\text { Trees and Shading devices such as } \\
\text { Awnings, canopies, building } \\
\text { protrusions. }\end{array}$ & $\begin{array}{l}\text { Jacobs (1993); Whyte } \\
\text { (1980) }\end{array}$ \\
\hline & $\begin{array}{l}\text { Good internal air } \\
\text { quality }\end{array}$ & $\begin{array}{l}\text { Cross breeze in semi open spaces. } \\
\text { Mechanical ventilation systems } \\
\text { within internal spaces. }\end{array}$ & $\begin{array}{l}\text { Gehl, (2010); Jacobs } \\
\text { (1993) }\end{array}$ \\
\hline \multirow{3}{*}{$\begin{array}{l}\text { Richness of } \\
\text { Experience }\end{array}$} & Façade details & $\begin{array}{l}\text { Vertical rhythm, depth, colours, } \\
\text { textures, detailing and signage of } \\
\text { facades that help create interest }\end{array}$ & Jacobs (1993) \\
\hline & Seatability & $\begin{array}{l}\text { Adequate amount of Comfortable } \\
\text { seating }\end{array}$ & Hertsberger (2005) \\
\hline & Lighting & Well-lit Satisfactory lighting & Whyte (1980) \\
\hline \multirow{3}{*}{$\begin{array}{l}\text { Richness of } \\
\text { Experience: }\end{array}$} & Internal enclosure & $\begin{array}{l}\text { Floor patterns, ceiling patterns and } \\
\text { wall placement. }\end{array}$ & $\begin{array}{l}\text { Clemente and Erwing } \\
\text { (2013); Cullen (1971); } \\
\text { Jacobs (1993); }\end{array}$ \\
\hline & Materiality & Usage of appropriate materials. & $\begin{array}{l}\text { Clemente and Ewing } \\
\text { (2013). }\end{array}$ \\
\hline & Signs and symbols & $\begin{array}{l}\text { Appropriate signage size and } \\
\text { positioning }\end{array}$ & Jacobs (1993) \\
\hline $\begin{array}{l}\text { Visual } \\
\text { permeability }\end{array}$ & $\begin{array}{l}\text { Understand ability } \\
\text { of the building or } \\
\text { the interior space } \\
\text { from outside. }\end{array}$ & $\begin{array}{l}\text { Out-out: ability to see and } \\
\text { recognize the building from } \\
\text { outside. Out - in: Ability to see } \\
\text { through to identify the public } \\
\text { activity inside the building }\end{array}$ & $\begin{array}{l}\text { Bentley (1985); Clemente } \\
\text { and Erwing (2013); Jacobs } \\
\text { (1993); Yavuz (2009); }\end{array}$ \\
\hline
\end{tabular}

\section{Climate Responsiveness}

Climate responsiveness in and around a public space increases the usability of the space (Gehl, 2010), thus it is important to ensure climate responsiveness of ETS. It can be achieved with use of external shading and maintaining good internal air quality (Jacobs, 1993; Whyte 1980). Whyte (1980) explains, sun and shade have a significant importance in the behaviour of public spaces. On the other hand, Jacobs (1993) argued that trees are the single most important element 
for good shading for many people who use public spaces. Cross breeze, Mechanical ventilation systems provide a comfortable environment within internal spaces (Gehl, 2010; Jacobs, 1993).

\section{Richness of Experience}

The richness of experience is a significant factor for public spaces. Aspects such as details, décor, rhythm, materials and textures can influence the responsiveness of public spaces and public interactions (Bentley, 1985; Hertsberger, 2005). Façade details, seatability, lighting, internal enclosure, materiality, signs, effective signs and symbols are key components of richness of experience (Jacobs, 1993). Effective signs and symbols can be achieved by the quality of visual appropriateness and appropriate signage size and positioning (Jacobs, 1993).

\section{Visual permeability}

Visual permeability refers to the ability to perceive activities beyond and within the street edge, where public and private realms meet (Clemente \& Erwing, 2013; Jacobs, 1993). Similarly, Yavuz (2009) elaborated that the degree of visual permeability depends on how well the building or the interior space is understandable from the outside.

\section{People's Perception (PP) of Entry Threshold Spaces (ETS)}

The components of a built environment often constitute and communicates the general meaning of that environment. The environment is full of coded information that needs to be decoded; thus, built environments need to be designed so that codes are clearly identified and understood by people (Rapoport, 1982). The perception of spatial properties (e.g. spaciousness) and the emotional responses (e.g. pleasure) towards a specific spatial configuration are closely linked (Franz, 2005) and perceptual space has emotional overtone (Matone, 1976).

Perception is accepting the received information from the surrounding environment. When the space is perceived, it becomes a self-conscious experience which links a sense of awareness and sensitivity within it. Through senses; sight, hearing, smell, taste, emotional bonds and touch; the mind holds personal experiences. Perception enables the ability to identify the environment which involves the processes of thinking, remembering, feeling etc. (Oosterhof and Todorov, 2008). Factors such as previous experiences, psychological needs of the users/ expectations, cultural factor, personal preferences, $\mathrm{PP}$ and the required behaviour patterns affects PP (Gray et al. 2007, Tamir et al. 2016 ).

\section{The Theoretical Framework}

In light of current literature, it is apparent that architectural responsiveness is linked to five attributes which are: physical permeability, human scale, climatic responsiveness, richness of experience and visual permeability. Accordingly, a new theoretical framework was developed and applied to investigate responsiveness and PP of ETS of public buildings. Refer figure 3.

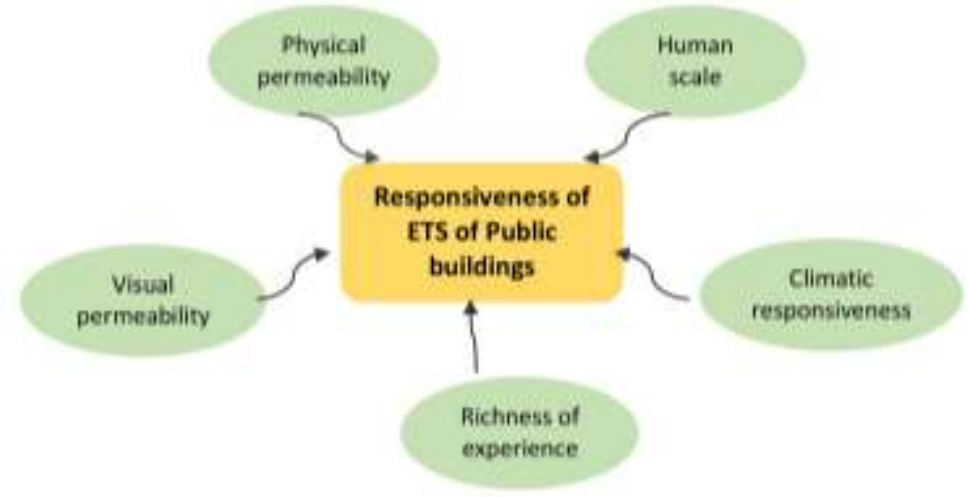

Fig. 2: Theoretical framework

Source: adopted from (Bentley, 1985; Clemente and Erwing, 2013; Hertsberger, 2005; Jacobs, 1993) 


\section{Research Methodology}

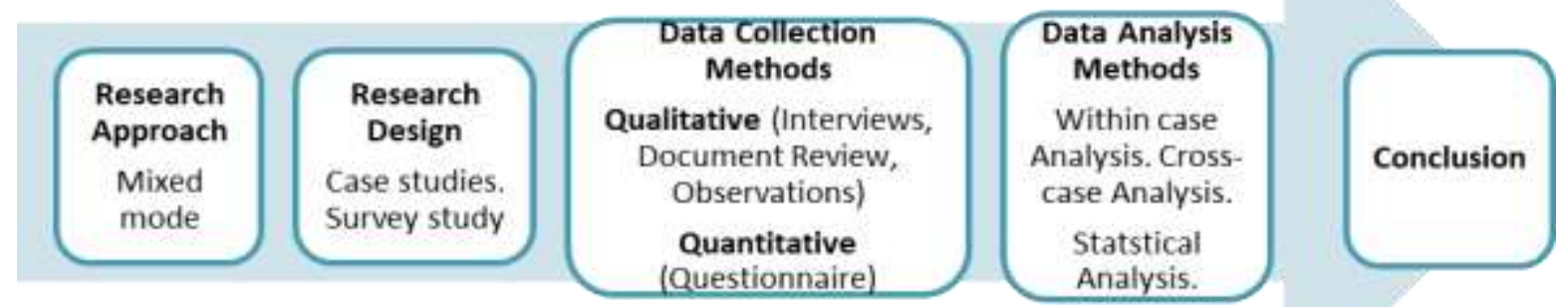

Fig. 4: Research Process Adopted for this Paper Source: Author

The Aim of this paper was to explore how to design ETS of public buildings in an architecturally responsive manner that can be well perceived by people. Due to the exploratory nature of how to design ETS of public buildings in an architectural responsive manner and the explanatory nature of PP, Mixed-mode research approach was followed throughout this research.

In order to carry out an in-depth analysis of how to design ETS of public buildings in an architectural responsive manner, qualitative case study approach was chosen and quantitative survey study was adopted to identify PP. Consequently, multiple cases were selected based on case study selection criteria, to obtain better analytical benefits. Case study selection criteria were:

a) Public buildings located in urban areas of Sri Lanka.

b) Public buildings that cater to distinctly different functions.

c) Public buildings owned by Government of Sri Lanka.

d) Public buildings that cater to more than 300 people on a functioning day.

e) Public buildings that comprised of all five components of entry thresholds spaces.

Accordingly, three cases were selected and they were: a) Mahinda Rajapakshe Nelum Pokuna Theatre (MRNPT) b) Magam Ruhunu International Convention Centre (MRICC) c) Bandaranayaka Memorial International Conference Hall (BMICH). Refer table 2 for a summary of details of cases selected.

Table 2: Summary of details of case studies

\begin{tabular}{|c|c|c|c|}
\hline & Case A: MRNPT & Case B: MRICC & Case C: BMICH \\
\hline Name & $\begin{array}{l}\text { Mahinda Rajapakshe } \\
\text { Nelum Pokuna Theatre }\end{array}$ & $\begin{array}{l}\text { Magam Ruhunupura } \\
\text { International } \\
\text { Convention Centre }\end{array}$ & $\begin{array}{l}\text { Bandaranaike Memorial } \\
\text { International } \\
\text { conference hall }\end{array}$ \\
\hline Location & Colombo & Hambanthota & Colombo \\
\hline Function & Performing art theatre & $\begin{array}{l}\text { Multi-functional facility } \\
\text { building (conventions, } \\
\text { exhibitions and events) }\end{array}$ & $\begin{array}{l}\text { Conference hall } \\
\text { (Conventions, Concerts, } \\
\text { Performances, Fairs, } \\
\text { Exhibitions, } \\
\text { Conferences, Seminars, } \\
\text { Workshops, Awards, } \\
\text { and Graduation } \\
\text { Ceremonies etc.) }\end{array}$ \\
\hline Ownership & $\begin{array}{l}\text { Government of Sri } \\
\text { Lanka }\end{array}$ & $\begin{array}{l}\text { Government of Sri } \\
\text { Lanka }\end{array}$ & $\begin{array}{l}\text { Government of Sri } \\
\text { Lanka }\end{array}$ \\
\hline $\begin{array}{l}\text { Average No of people } \\
\text { visit the building. }\end{array}$ & $700-1200$ & $800-1500$ & $100-1600$ \\
\hline $\begin{array}{l}\text { No of Components of } \\
\text { ETS is comprised with }\end{array}$ & Five & Five & Five \\
\hline
\end{tabular}


In order to collect data from three cases, semi-structured face-to-face interviews, observations and document review were carried out. Accordingly 6 profiles were interviewed. Refer table 3 for a summary of their details.

Table 3: Profiles of Interviewees

\begin{tabular}{|l|l|}
\hline \multicolumn{1}{|c|}{ Case study } & \multicolumn{1}{c|}{ Description } \\
\hline Case A: MRNPT & $\begin{array}{l}\text { Interviewee 1: Senior Administrative Officer } \\
\text { Interviewee 2: Member of Board of Management }\end{array}$ \\
\hline Case B: MRICC & $\begin{array}{l}\text { Interviewee 3: Senior Administrative Officer } \\
\text { Interviewee 4: Director Design }\end{array}$ \\
\hline Case C: BMICH & $\begin{array}{l}\text { Interviewee 5: Senior Administrative Officer } \\
\text { Interviewee 6: Director Events }\end{array}$ \\
\hline
\end{tabular}

In addition, documents such as reports, pictures and drawings were reviewed and field notes were recorded based on observations made. Further, a random sampling questionnaire was carried out to collect data for the survey study to identify PP. Accordingly responses from 50 individuals of each case who visited them were obtained. Thereby, a total of 150 responses were obtained. Public response on 14 components of physical attributes were assessed, and there by PP on five physical attributes of responsiveness of ETS were analysed. People were asked to rate level of perception as High, Moderate or Low. Collected data was analysed within case and cross case wise and final conclusions were drawn.

\section{Limitations}

Due to difficulties in accessing documents of MRNPT, only a limited number of drawings were reviewed. Further, time allowed for observations inside MRICC premises was challenging due to security reasons, thus only a limited time was spent to observe architectural elements of ETS of MRICC.

\section{Findings and Analysis}

Findings related to fourteen components of Physical Attributes of architectural responsiveness of ETS are discussed below.

\section{STREET EDGE TREATMENT}

Findings revealed that all three cases were with secure pedestrian networks. Pedestrian network of MRICC was comprised of steps along the approach way which was about $100 \mathrm{~m}$ long, while the BMICH had two identifiable pedestrian networks for in and out pedestrians. Even though MRNPT was not with green shady areas, MRICC was observed to have planters along pathways which provided ample shade to pedestrians. At BMICH, trees on either sides of the gates provided green shady areas, however, the trees on the sides of pathways were located too far away from the pedestrian and thus they were observed to be less useful to provide shade for people. Accordingly the qualitative inquiry identified that the architectural elements of street edge treatment of BMICH was moderate for public movement while it was high at MRICC and $\mathrm{BMICH}$. 


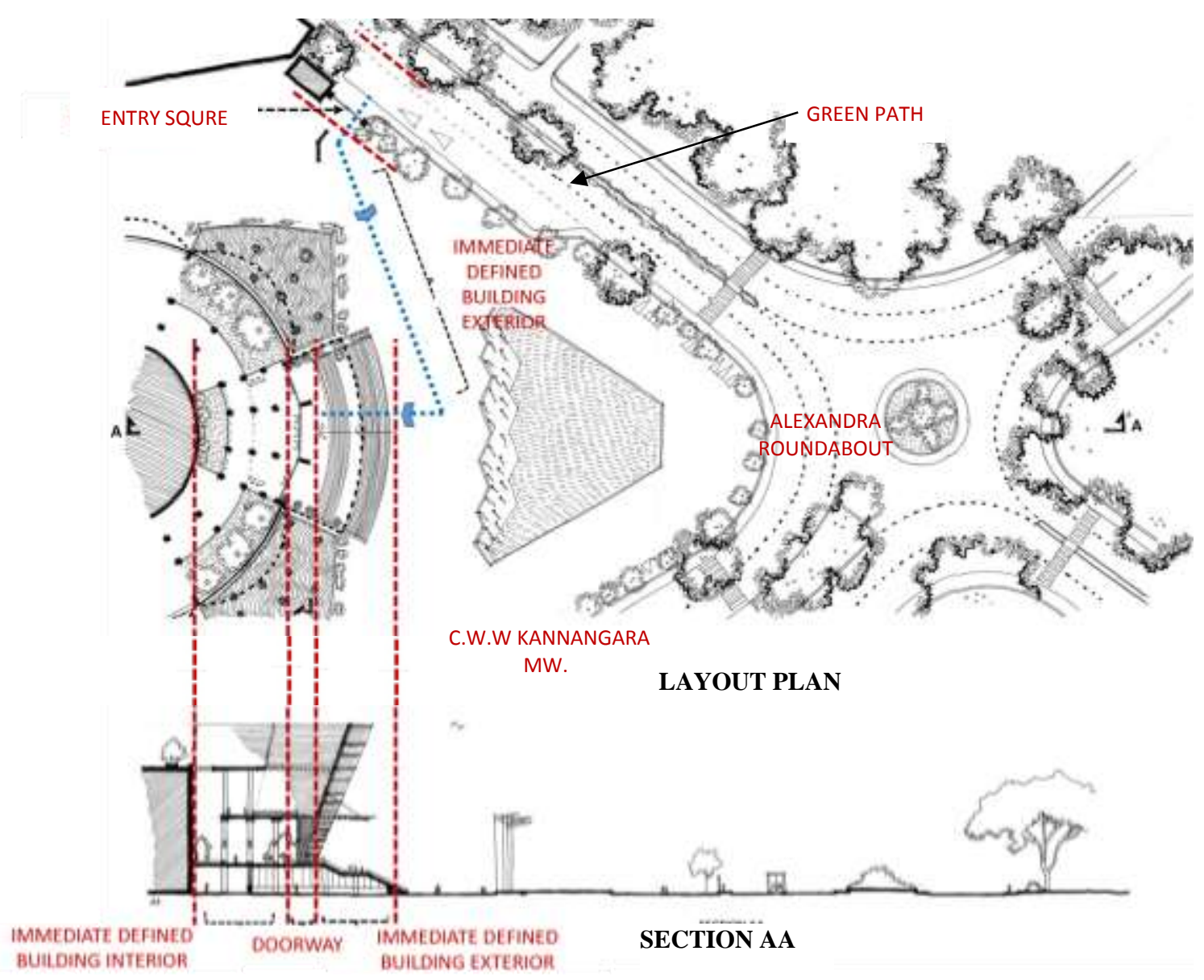

Fig. 5: Entry threshold space of MRNPT Source: by author

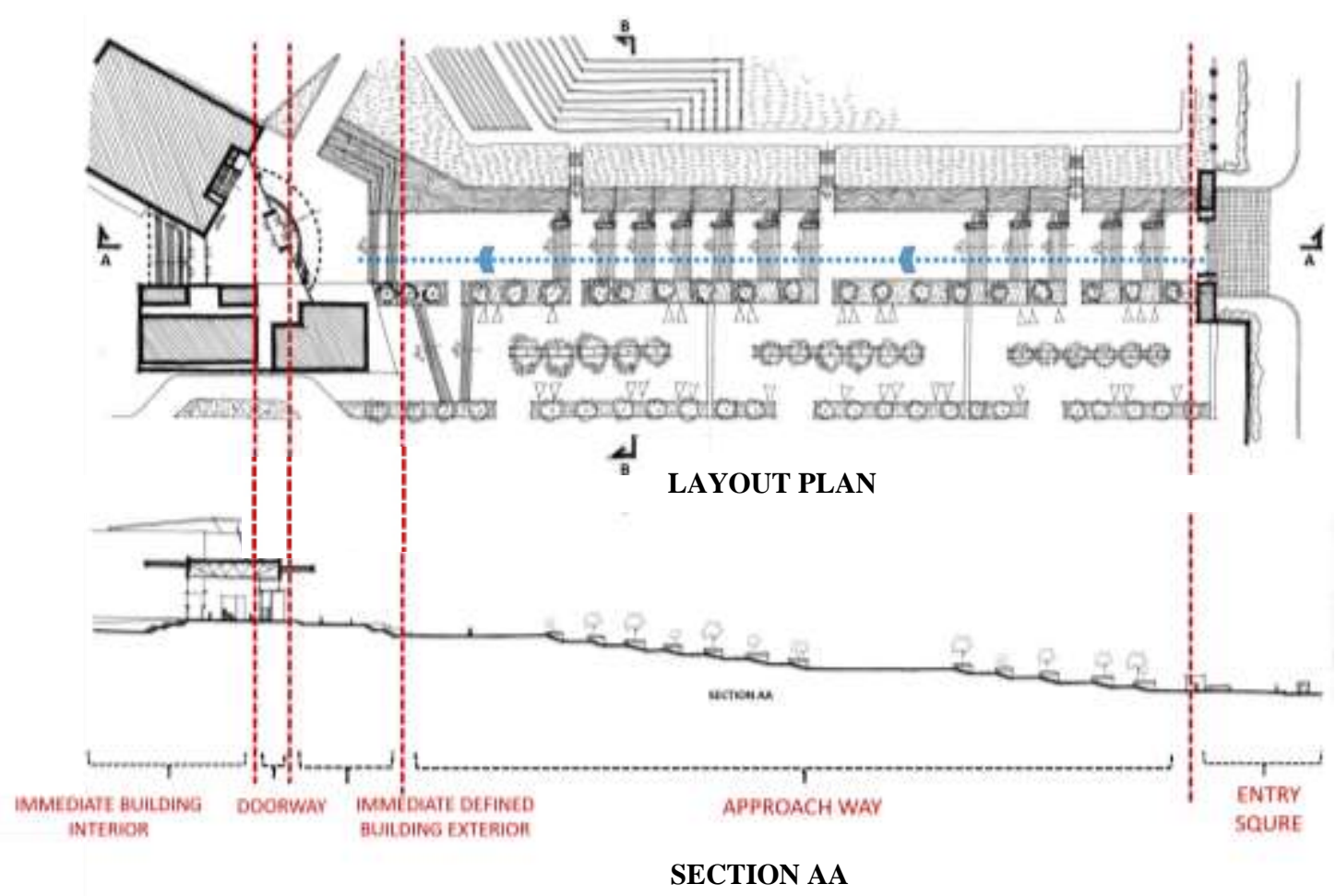

Fig. 6: Entry threshold space of MRICC

Source: by author 


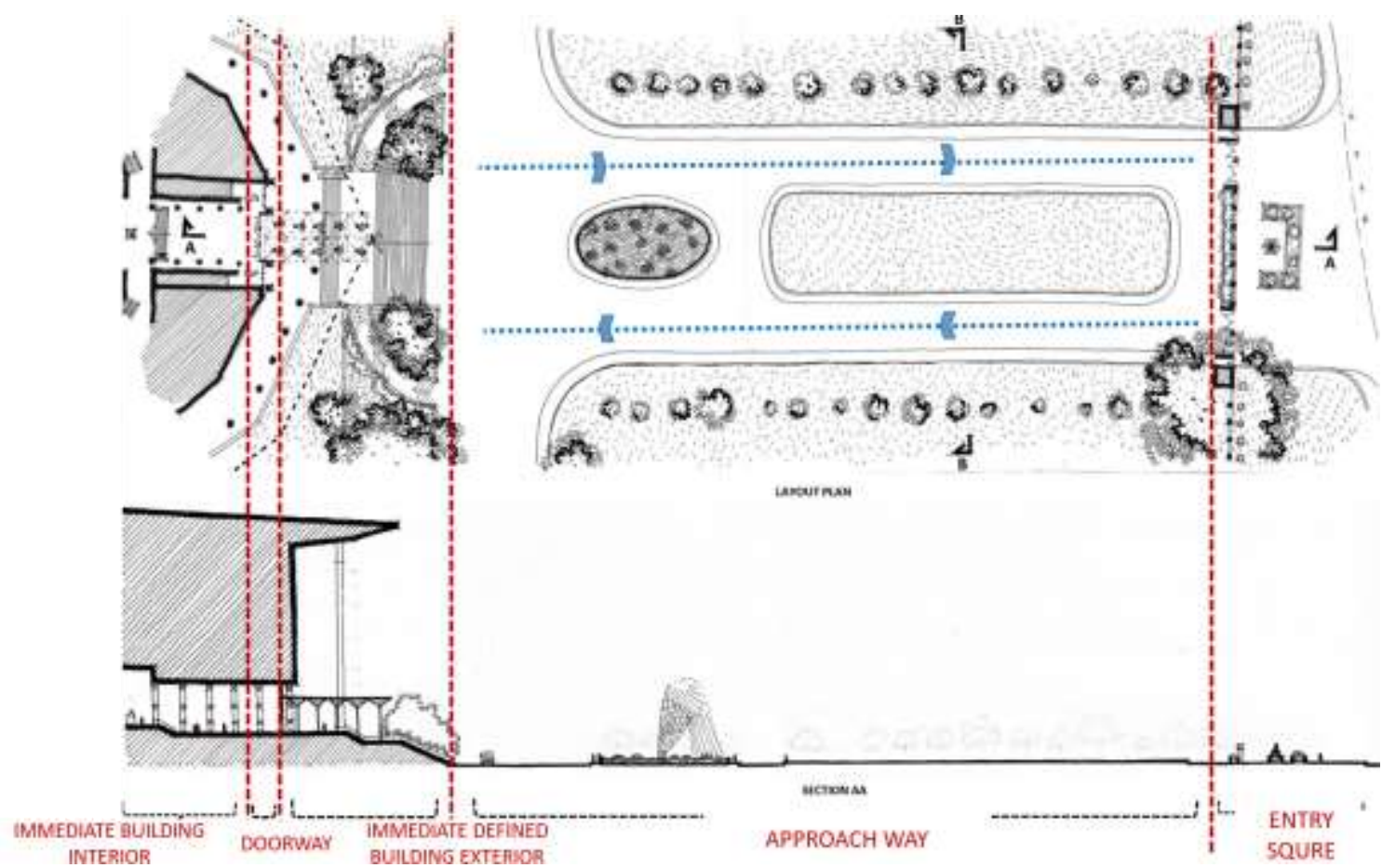

Fig. 7: Entry threshold space of BMICH Source: by author

Similarly, responses obtained from the public revealed that the PP on street edge treatment of MRNPT was moderate while it was high at MRICC and BMICH. Refer figure 8.

(a)

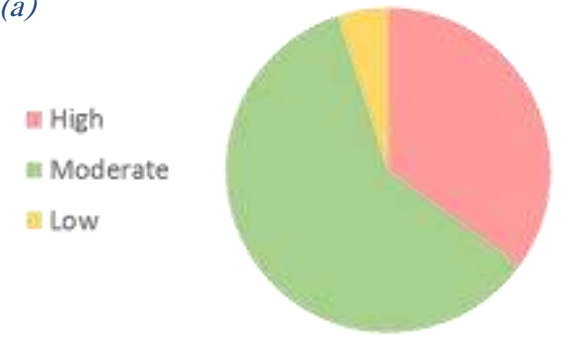

(b)

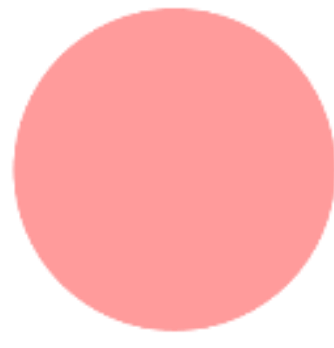

(c)

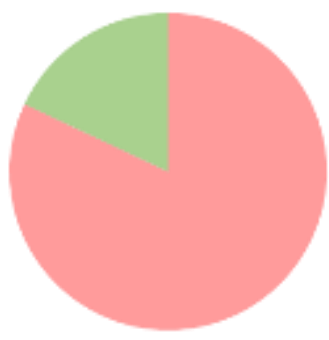

Fig. 8: Public response on street edge treatment (a) MRNPT, (b) MRICC, (c) BMICH Source: author

\section{PUNCTUATION}

It was identified that shallow ponds on either sides of podiums at the immediate interior space functioned as gaps, creating punctuations at MRNPT. However, gaps between pedestrian pathways and line of trees did not create effective punctuations at $\mathrm{BMICH}$, as the gaps were too wide to function as urban pauses. No gaps were identified at MRICC. Hidden spaces which makes punctuations were not identified at MRNPT and BMICH. However, parking spaces at MRICC, which were linked to the approach way were observed to function as hidden punctuation spaces as people were gathered around planters at the parking area. The promenade at the end of the approach way which is located before the stairway leading towards the entry forecourt at MRICC, was identified as a break that created a punctuation. Similarly, planters along the approach way of MRICC, break the monotony and landings which linked the in and out pedestrian network. At $\mathrm{BMICH}$, ledges along the water fountain and the peripheral passage that runs around the main building was identified as breaks that created punctuations that made urban pauses. However, no significant breaks were identified at MRNPT. Accordingly, the qualitative inquiry identified that 
the architectural elements of punctuations were moderate at MRNPT and MRICC while it was high at the BMICH.

On the other hand, responses obtained from the public revealed that the PP on punctuality was high at all three cases. Refer figure 9.

(a)

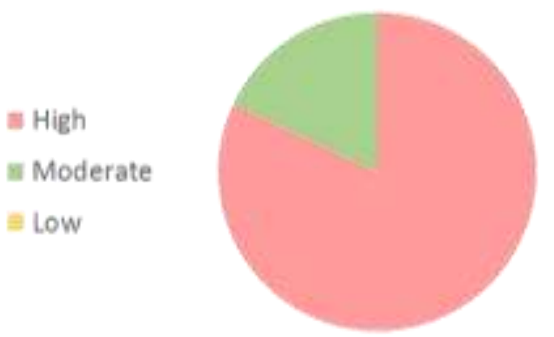

(b)

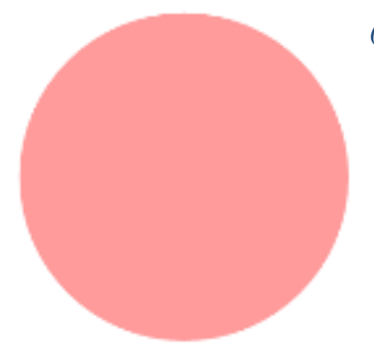

(c)

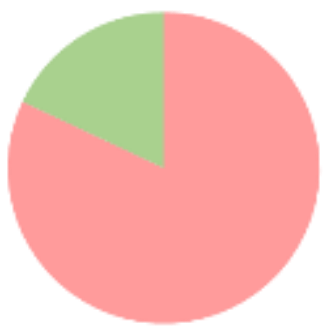

Fig. 9: Public response on Punctuation (a) MRNPT, (b) MRICC, (c) BMICH Source: author

\section{HEIGHT-WIDTH/DISTANCE RATIO}

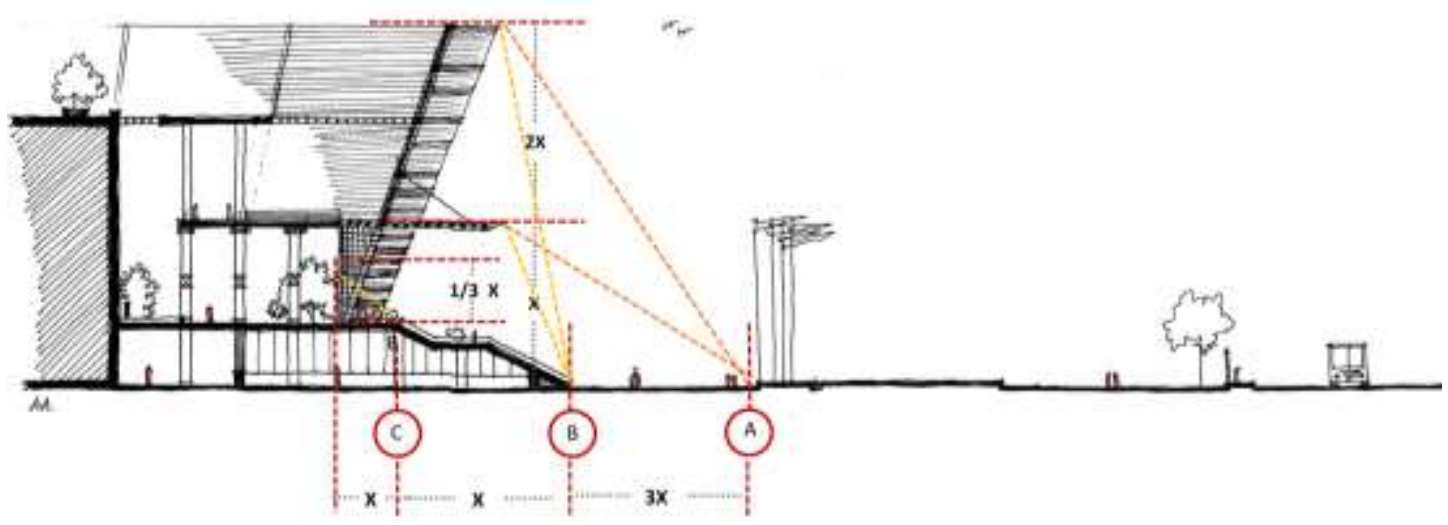

Fig. 10: Height to distance ratio of Nelum Pokuna Theatre Source: by author

At MRNPT as seen in Fig. 10, at point 'A', the entire building is shown at the ratio of 3:4, which is higher than the appropriate ratio. The ratio is 1:4 from ' $\mathrm{A}$ ' to the canopy, which is lesser than the ideal 1:2 or 1:3 ratio. At point ' $\mathrm{B}$ ' (beginning of the staircase), the building is experienced in the ratio of 3:1, which is higher than the appropriate ratio. The ratio is $1: 1$ from the canopy to ' $\mathrm{B}$ ', which is not within the appropriate range as well. At point ' $\mathrm{C}$ ' (starting point of the podium) the ratio towards the main doorway is, $1 / 3: 1$, which is within the appropriate range

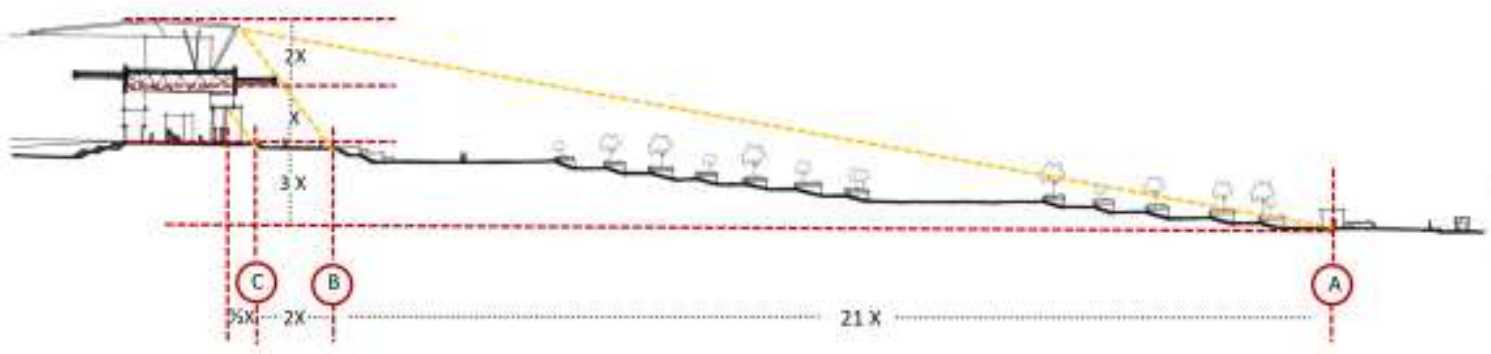

Fig. 11: Height to width ratio of MRICC

Source: by author 
At MRICC, as seen in figure 11, at point ' $A$ ' the ratio of the entire building is 6:21, which is lower than the 1:2 or 1:3 ratio (height of the approach way steps also taken into the overall building height). The canopy of the building is not calculated as the canopy is not identified clearly at this point. At point ' $\mathrm{B}$ ', the ratio of the overall building is $3: 2$, which is lower than the appropriate ratio. The ratio for the canopy from the same point is $1: 2$ which is within the ratio. At point ' $\mathrm{C}$ ' (doorway) the ratio is $1: 1 / 2$, which is higher than $1: 2$ or $1: 3$ ratios.

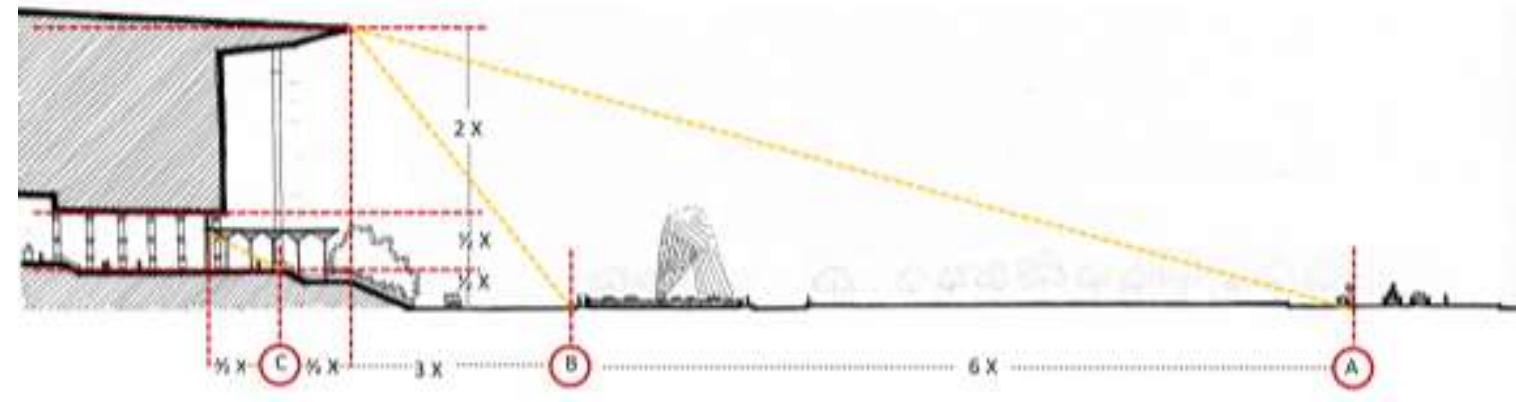

Fig. 12: Height to width ratio of BMICH Source: by author

At BMICH, as seen in figure 12, at point ' $\mathrm{A}$ ' the ratio of the entire building is 3:9 (1:3), which is an appropriate ratio. The ratio of the extended glass canopy from the point ' $A$ ' is $1: 9$, which isless than $1: 2$ or $1: 3$ ratios. At point ' $\mathrm{B}$ ', the ratio of the building is $3: 3(1: 1)$ which is higher than the appropriate ratios. Glass canopy ratio from point ' $\mathrm{B}$ ' is $1: 3$, which is within the ratio. At point ' $\mathrm{C}$ ' (at the main doorway), the ratio is $1 / 4: 1 / 2$, which is not within the ratio.

On the other hand, Responses obtained from public revealed that the PP on height width ratio was high at all three cases. Refer figure 13.

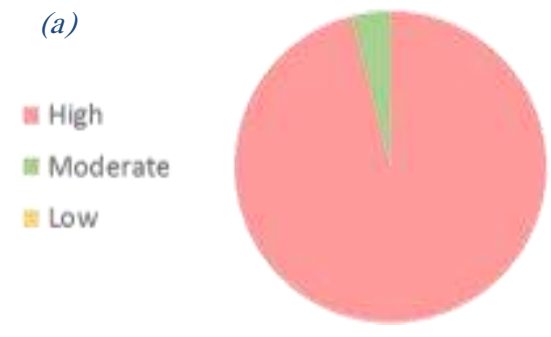

(b)

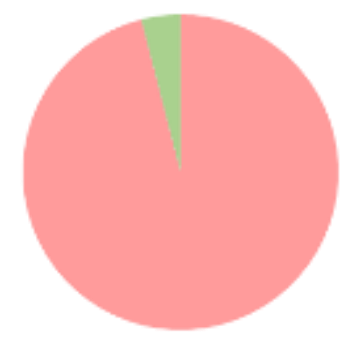

(c)

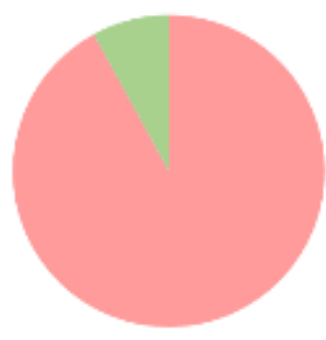

Fig. 13: Public response on height width ratio (a) MRNPT, (b) MRICC, (c) BMICH Source: author

\section{ADEQUATE WALKING SPACES}

Wide approach ways at MRNPT and MRICC provided adequate walking spaces to pedestrians. However, the dedicated approach way for pedestrians at the BMICH was barely sufficient. Pedestrian ramps at MRNPT were not a part of the ETS. Despite the presence of pedestrian ramps at MRICC, they were not linked to the pedestrian pathway, although adequate ramps were observed to be located adjacent to the vehicular access. Similarly, two adequate ramps were identified at the end of the approach way of BMICH. Wide steps at all three cases were identified to provide adequate walking spaces. Seven sets of timber doors at MRNPT, double doors at MRICC and the three segmented main doorway at BMICH were identified to provide 
adequate space for entry. Accordingly, the qualitative inquiry identified that the adequacy of architectural elements of walking spaces were high at all three cases.

Similarly, responses obtained from the public revealed that the PP on adequacy of walking were rated high at all three cases. Refer figure 14.

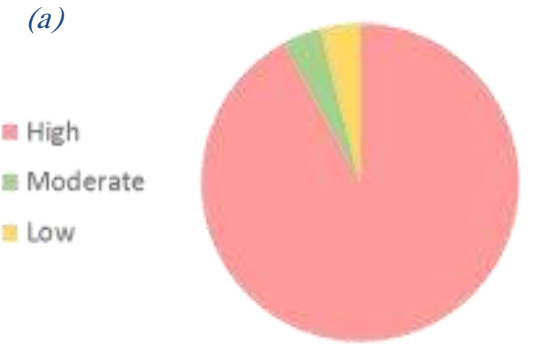

(b)

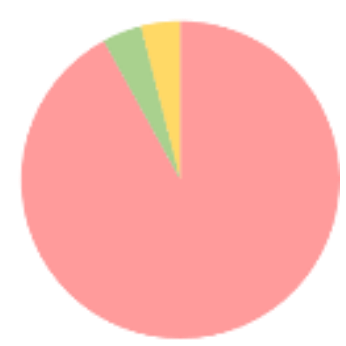

(c)

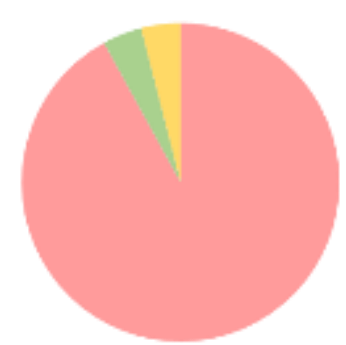

Fig. 14: Public response on adequate walking spaces (a) MRNPT, (b) MRICC, (c) BMICH Source: author

\section{LARGE IMMEDIATE INTERNAL BUILDING VOLUME}

The triple height space of approximately $25^{\prime}$ high volume that follows the main doorway and the court yard which was $45^{\prime}$ high, created a large immediate internal building volume at the MRNPT. Similarly, the large volume supported by trusses at the immediate building interior of MRICC, also observed to create a large immediate internal building volume, despite the relatively low ceiling, due to penetrations created at the ceiling which allows the users to feel the vast structural height of the space. However, the height of the main lobby (immediate interior) was less at BMICH compared to the immediately defined exterior space. In addition, an atrium with a large volume filled with natural light created a large immediate internal building volume at MRNPT, while such effective atriums were not observed at MRICC and BMICH. Accordingly, the qualitative inquiry identified that the architectural elements that provide large immediate internal building volume were high at MRNPT, while it was moderate at MRICC and BMICH.

On the other hand, responses obtained from the public revealed that the PP on large immediate internal building volume were high at MRNPT and BMICH while it was moderate at MRICC. Refer figure 15

(a)

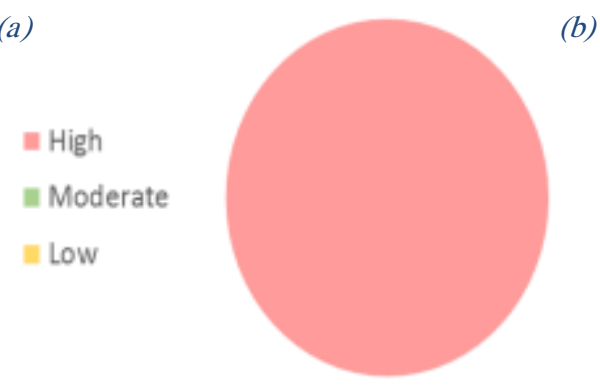

(b)

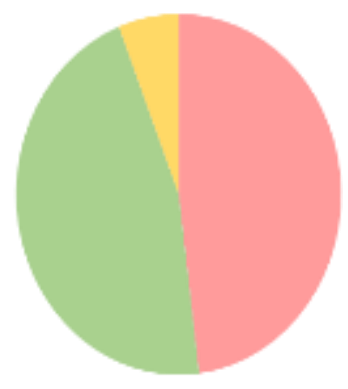

(c)

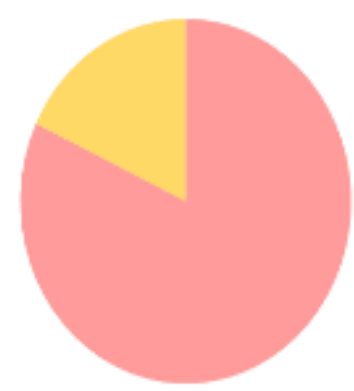

Fig. 15: Public response on immediate internal building volume (a) MRNPT, (b) MRICC, (c) BMICH Source: author

\section{EXTERNAL SHADING}

Building projections and an overhanging canopy at immediate defined exterior space provided external shading at MRNPT. Similarly, building projections at immediate defined exterior space provided external shading at MRICC. However, curved shaped canopies provided less shade at 
MRICC. The projected building mass at BMICH provided shelter for the main doorway. However, the extended glass canopy, which is about $75 \mathrm{ft}$. above, is not effective as a protection against the sun. Trees were planted along the boundary of the MRNPT, yet, did not provide adequate shade. Similarly, large planters along the approach way of MRICC and green islands with frangipani trees were observed to provide shade inadequately. On the other hand, two large trees adjoining the security posts at BMICH and foliage adjoining the ramps on either side of the main staircase, provided ample shade. However, line of trees along the approach way were located too far away from pedestrian pathways, thus, did not provide shade for people. Accordingly the qualitative inquiry identified that the architectural elements of external shading of MRNPT and BMICH was moderate while it was low at MRICC.

Similarly, responses obtained from the public revealed that the PP on external shading of MRNPT and BMICH was moderate while it was low at MRICC. Refer figure 16.

(a)

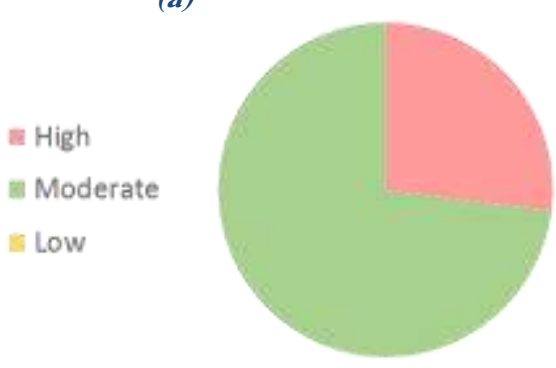

(b)

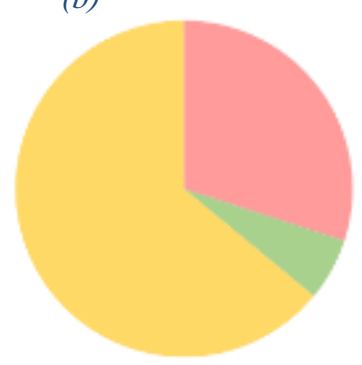

(c)

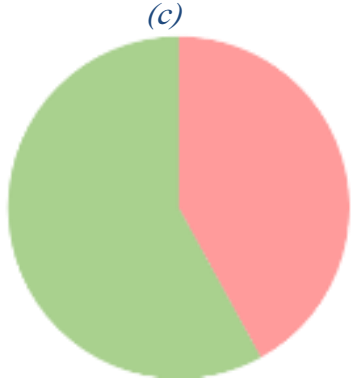

Fig. 16: Public response on external shading(a) MRNPT, (b) MRICC, (c) BMICH Source: author

\section{GOOD INTERNAL AIR QUALITY}

Even though there a courtyard was observed at MRNPT, semi open spaces with cross breeze was not identified as the courtyard was walled with glass. Similarly, semi open spaces were not observed at MRICC and BMICH as well. Immediate interior spaces of MRNPT was enclosed, yet no mechanical ventilation was provided. Thus, the internal air quality was poor. On the other hand, the immediate interior space of MRICC was air conditioned and performance glass on exterior wall cut off direct sun light entering in to the space. Thus a comfortable air quality was identified. Similarly, immediate interior space (the lobby) of BMICH was also air conditioned and the projected outer mass of the building cuts off direct sunlight penetrating through the glass façade in to the lobby. Thus a comfortable air quality was identified. Accordingly the qualitative inquiry identified that the architectural elements related to good internal air quality was low at MRNPT and high at MRICC and BMICH.

Similarly, responses obtained from the public revealed that the PP on internal air quality was low at MRNPT and high at MRICC and BMICH. Refer figure 17.
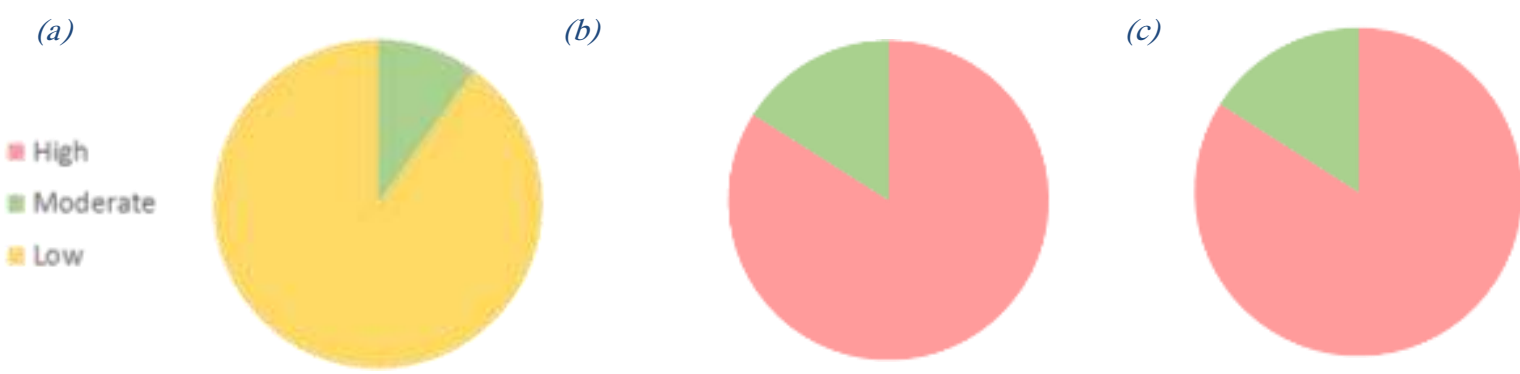

Fig. 17: Public response on good internal air quality (a) MRNPT, (b) MRICC, (c) BMICH Source: author 


\section{FAÇADE DETAIL}

The façade of the MRNPT was divided into eight segments vertically with use of structural elements and horizontal rhythm was highlighted by use of orange coloured rings. The same elements created a depth in the facade as well. Further, the façade at MRICC was divided in to 3 segments horizontally (varying heights) and vertically (varying widths), thereby maintaining vertical and horizontal rhythm. Presence of similar elements and canopies created a depth in the facade as well. It was observed that at $\mathrm{BMICH}$, vertical rhythm was highlighted with the use of pillars. A horizontal rhythm was also achieved with the use of glass louvers, though it was not noticeable from a distance. However, play of depth was not noticeable at the façade of the BMICH. Colours such as dark grey and orange were used at MRNPT and white bronze was used at MRICC, while BMICH used predominantly white for the façade with a red coloured band at the ground floor. The front entrance at MRNPT consisted of textures, while random groves were observed at the façade cladding of MRICC which created a texture. Significant textures were not noticeable at BMICH. Signage used to detail the façade was not identified at all three cases. Accordingly the qualitative inquiry identified that the architectural elements used for façade detailing was high at MRNPT and moderate at MRICC and BMICH.

On the other hand, responses obtained from the public revealed that the PP on façade detailing was high at all three cases. Refer figure 18.
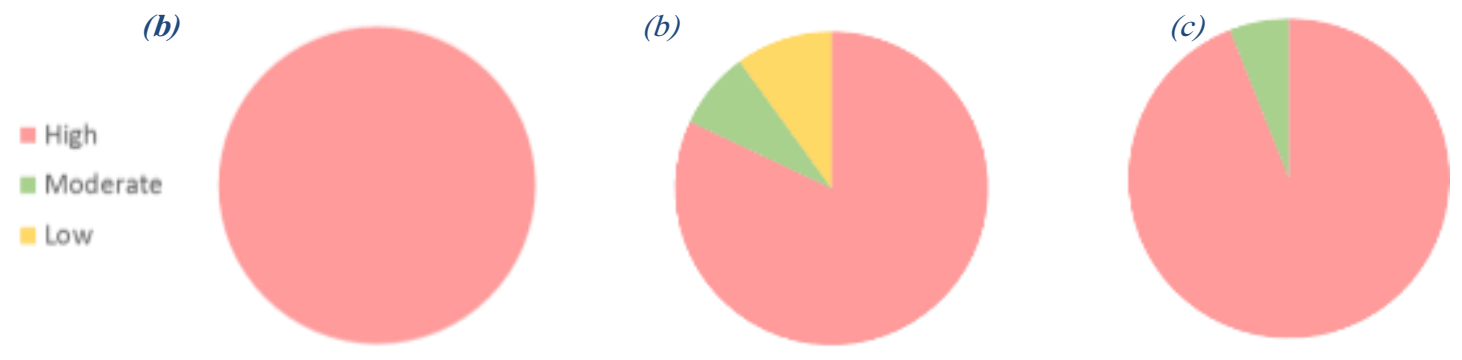

Fig.18: Public response on façade detail (a) MRNPT, (b) MRICC, (c) BMICH Source: author

\section{SEATABILITY}

Few informal seating areas were provided at the interior of MRNPT. However, adequate seating was not identified in the immediate exterior nor immediate interior space of MRNPT. On the other hand, few seating spaces provided at the entry square, open air theatre (500 seating capacity) located adjacent to the approach way, walls of planters and ponds along the approach way provided ample seating spaces at MRICC. The immediate interior of MRICC was observed to have no seating, but was linked to a separate space with seating. Similarly, inbuilt seating facilities were identified as landscape features such as the seating ledge around the water fountain, guard walls on either side of the staircase and ramps at BMICH. Further informal seating was provided at the outer periphery of the passage that runs around the building. However formal seating provided in the immediate interior space on either side of the doorway were inadequate. Accordingly, the qualitative inquiry identified that the architectural elements of seatability was low at MRNPT while it was moderate at MRICC and BMICH.

Similarly, responses obtained from the public revealed that the PP on seatability was also low at MRNPT while it was moderate at MRICC and BMICH. Refer figure 19. 

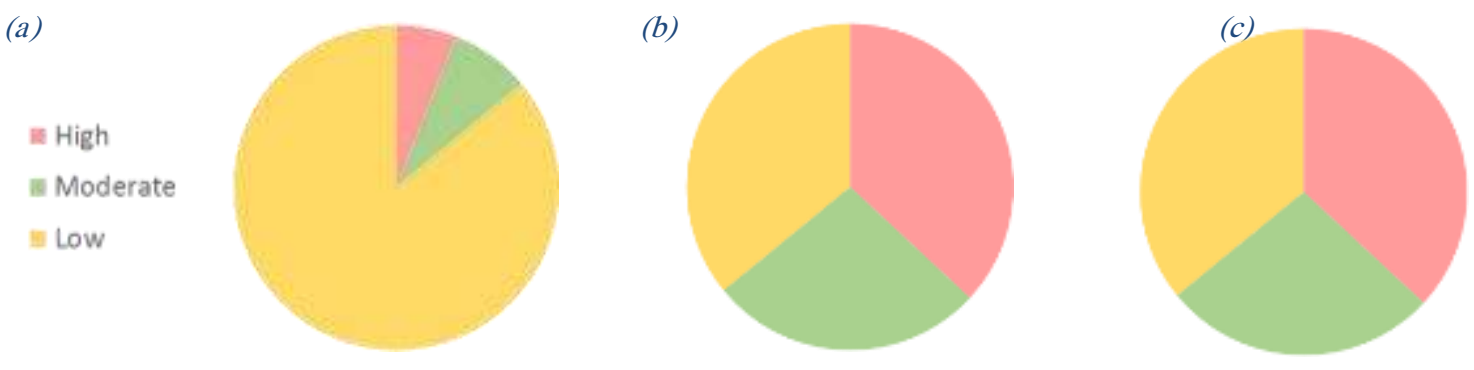

Fig.19: Public response on seatability (a) MRNPT, (b) MRICC, (c) BMICH Source: author

\section{LIGHTING}

Adequate lighting was observed during daytime at the entire ETS of MRNPT. Further, the glass façade provided ample daylight to the immediate interior space and the light well in this space served to highlight the feature wall present. While vibrant artificial lighting was observed to highlight the façade at night, less lighting emphasis was noticed at entry square and approach way. However, grid patterned lighting was observed at immediate exterior space. Similarly, adequate lighting was observed during daytime at the entire ETS of MRICC. The canopy at immediate exterior space cut-off the direct sunlight falling on to the space. Interviewees revealed that the performance glass of the façade was used to filter sunlight. Special lighting features were observed for the cascading ponds along the approach way and groves of the facade were well lit at night. However the overall lighting condition of the entire ETS was marginal. At BMICH both natural and artificial lights were used to light the ETS during daytime. At night, the ETS was lit up with vibrant colours. The façade at immediate exterior space was highlighted by warm coloured lighting. Accordingly the qualitative inquiry identified that the architectural elements of lighting was moderate at all three cases.

On the other hand, responses obtained from the public revealed that the PP on lighting was high at MRNPT, moderate at MRICC and low at BMICH. Refer figure 20.
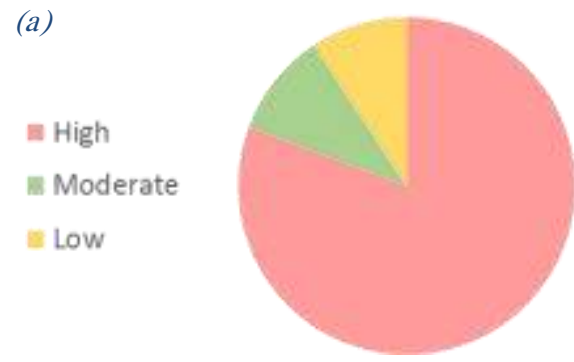

(b)

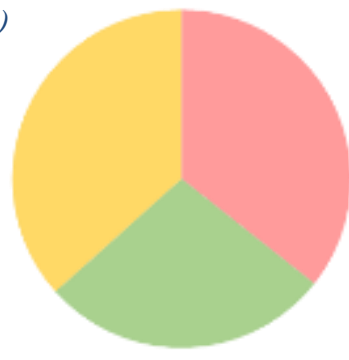

Fig.20: Public response on lighting (a) MRNPT, (b) MRICC, (c) BMICH

Source: author

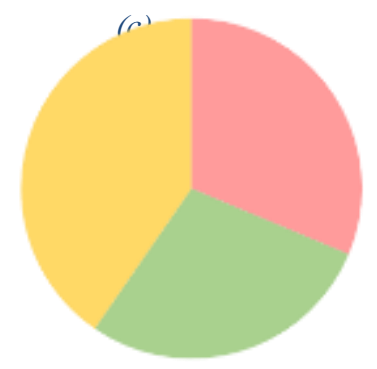

\section{INTERNAL ENCLOSURE}

Floor and ceiling patterns were not observed at internal enclosure of MRNPT. However they were observed that MRICC, where both floor and ceiling patterns provided a directional quality towards the main auditorium. Similarly the rectangular floor and ceiling patterns at BMICH was also observed to be corresponding to each other. A brick wall at MRNPT that was highlighted among white coloured walls added to the richness of the experience. Non-rectangular wall placement was observed at MRICC, while it was rectangular at BMICH. Accordingly the qualitative inquiry identified that the architectural elements of internal enclosure was moderate at all three cases. 
On the other hand, responses obtained from the public revealed that the PP on internal enclosure was low at MRNPT, while it was moderate at MRICC and BMICH. Refer figure 21.
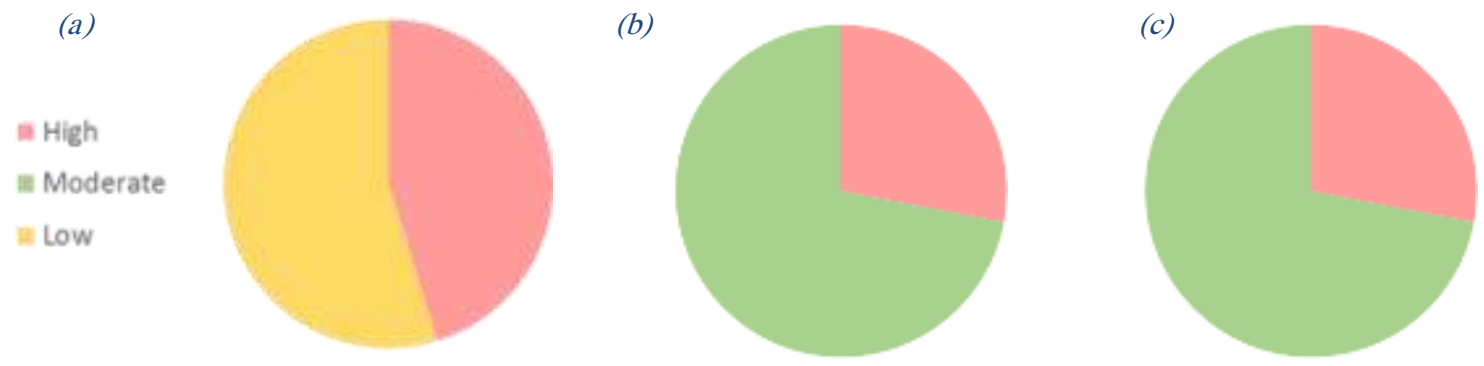

Fig. 21: Public response on internal enclosure (a) MRNPT, (b) MRICC, (c) BMICH Source: author

\section{MATERIALITY}

Materials used at the entry square, approach way, immediate defined building exterior and immediate building Interior of MRNPT were commendable. Materials on the façade of the building were glass, steel and timber; which contributed to the richness of the experience. Concrete paving and tiles made out of ceramic were observed at the entry square and approach way of MRICC. While ceramic tiles for the floor and reflective materials for the soffit of the canopy were used at immediate exterior. Similarly, ceramic tiles for the floor and gypsum board were used for the soffit at immediate building Interior, which added to the richness of the experience. At $\mathrm{BMICH}$, different stone paving patterns were used for the approach way and glass was used for the façade and for the entrance canopy. It was observed that walls, columns, and floors were clad with different shades of granite at the immediate interior (lobby). Accordingly, the qualitative inquiry identified that the architectural elements related to materiality was moderate at MRICC while it was high at MRNPT \& BMICH.

On the other hand, responses obtained from the public revealed that the PP on materiality were high at all three cases. Refer figure 22.
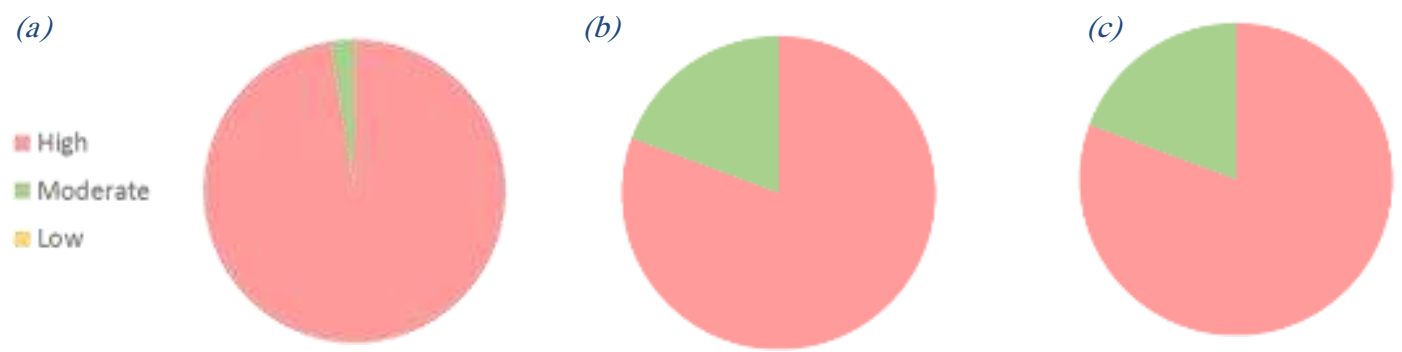

Fig. 22: Public response on Materiality (a) MRNPT, (b) MRICC, (c) BMICH

\section{SIGNS AND SYMBOLS}

Carvings were observed on circular columns at MRNPT, and document review revealed that they were derived from carvings of Embekke Devalaya. Furthermore, carvings of flower motifs were observed on the railings. In addition appropriate signage was observed. While no symbols were observed at MRICC, signage on the boundary wall and the rooftop were observed. A large scale national emblem was observed on the building façade, which symbolized that it was a state owned building. Flower motifs were observed on the architrave of the doorway, which symbolized the cultural elements of Sir Lanka. Further appropriate signage was observed throughout the ETS. Accordingly the qualitative inquiry identified that the architectural elements of signs and symbols was high at MRNPT and BMICH while it was moderate at MRICC. 
On the other hand, responses obtained from the public revealed that the PP on signs and symbols were high at all three cases. Refer figure 23.
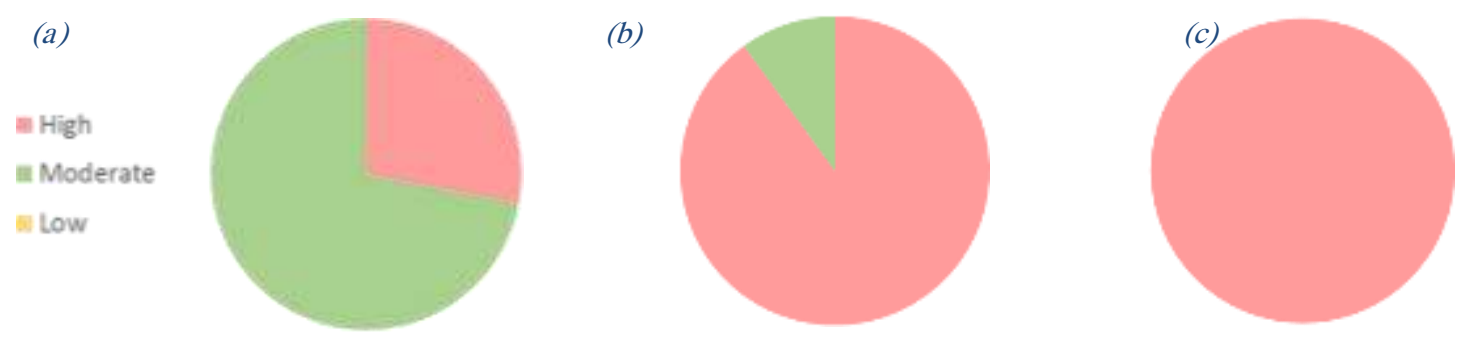

Fig. 23: Public response on Signs \& Symbols (a) MRNPT, (b) MRICC, (c) BMICH

\section{VISUAL PAERMEABILITY}

The main external entrance at MRNPT and MRICC has an oblique approach. A direct visual link towards the main entrance is not formed both in MRNPT and MRICC upon entering from the main external entry way. The visibility of MRNPT was poor in-between the entry square and the defined immediate exterior space, but was strong at MRICC. The screen at the immediate defined building exterior was transparent. Hence, visibility from immediate exterior to the immediate building interior was strong. However, the visual link (out-out) was strong at BMICH due to a frontal approach. Since the entrance doorway was transparent, the visibility from the immediate exterior to the immediate interior building at all three cases was strong. Accordingly the qualitative inquiry identified that the architectural elements of visibility was moderate at MRNPT while it was high at BMICH and MRICC.

Similarly, responses obtained from the public revealed that the PP on visibility were high at all three cases. Refer figure 24.

(a)

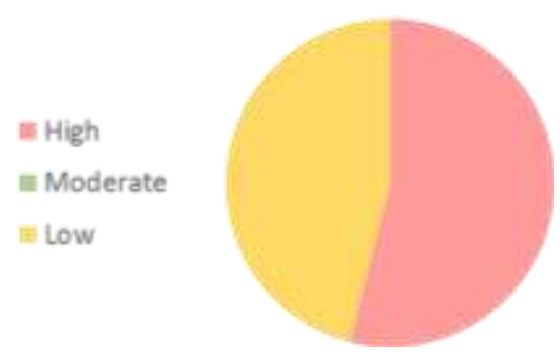

(b)

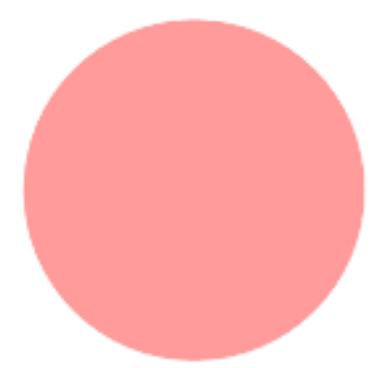

(c)

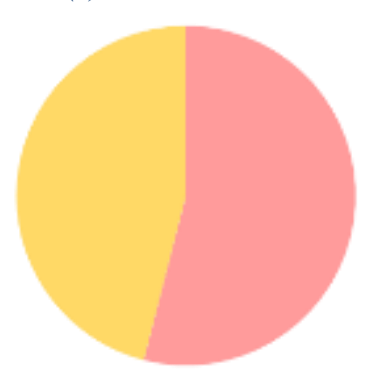

Fig. 24: Public response on visibility (a) MRNPT, (b) MRICC, (c) BMICH

Source: author

Refer table 4 for a summary of cross case analysis. 
Cities People Places; Vol. 4, Issue 2: December, 2020

Table 4: Cross case analysis

\begin{tabular}{|c|c|c|c|c|c|c|c|}
\hline \multirow{2}{*}{$\begin{array}{l}\text { Physic } \\
\text { al } \\
\text { Attrib } \\
\text { utes }\end{array}$} & \multirow{2}{*}{$\begin{array}{l}\text { Components } \\
\text { of physical } \\
\text { attributes of } \\
\text { entry } \\
\text { threshold } \\
\text { space }\end{array}$} & \multicolumn{6}{|c|}{ Findings from Case Studies } \\
\hline & & \multicolumn{2}{|c|}{$\begin{array}{l}\text { Mahinda Rajapakshe } \\
\text { Nelum Pokuna Theatre } \\
\text { (MRNPT) }\end{array}$} & \multicolumn{2}{|c|}{$\begin{array}{l}\text { Magam Ruhunupura } \\
\text { International } \\
\text { Convention Centre } \\
\text { (MRICC) }\end{array}$} & \multicolumn{2}{|c|}{$\begin{array}{c}\text { Bandaranayake } \\
\text { Memorial International } \\
\text { Conference Hall (BMICH) }\end{array}$} \\
\hline \multirow{3}{*}{$\begin{array}{l}\text { Physic } \\
\text { al } \\
\text { Perme } \\
\text { ability }\end{array}$} & \multirow{2}{*}{$\begin{array}{l}\text { Street edge } \\
\text { with public } \\
\text { movement }\end{array}$} & Remarks & PP & Remarks & PP & Remarks & PP \\
\hline & & $\begin{array}{l}\text { Shady green } \\
\text { areas were not } \\
\text { effective. } \\
\text { Secured } \\
\text { pedestrian } \\
\text { network and } \\
\text { forecourt were } \\
\text { there but } \\
\text { seating was } \\
\text { inadequate. }\end{array}$ & $\begin{array}{l}\text { Mode } \\
\text { rate: }\end{array}$ & $\begin{array}{l}\text { Shady green } \\
\text { areas, secured } \\
\text { pedestrian } \\
\text { network, } \\
\text { forecourt with } \\
\text { seating } \\
\text { arrangements } \\
\text { was present. }\end{array}$ & High & $\begin{array}{l}\text { Shady green } \\
\text { areas were not } \\
\text { effective; but, } \\
\text { secured } \\
\text { pedestrian } \\
\text { network, } \\
\text { forecourt and } \\
\text { adequate seating } \\
\text { was present. }\end{array}$ & High \\
\hline & Punctuations & $\begin{array}{l}\text { Gaps, breaks } \\
\text { between two } \\
\text { existences } \\
\text { were present. } \\
\text { Hidden spaces, } \\
\text { were not } \\
\text { present. }\end{array}$ & High & $\begin{array}{l}\text { No gaps found. } \\
\text { Hidden spaces, } \\
\text { distances and } \\
\text { breaks } \\
\text { between two } \\
\text { existences was } \\
\text { present. }\end{array}$ & High & $\begin{array}{l}\text { Gaps were not } \\
\text { effective; but } \\
\text { hidden spaces, } \\
\text { distances, } \\
\text { breaks between } \\
\text { two existences } \\
\text { was present. }\end{array}$ & High \\
\hline \multirow[t]{3}{*}{$\begin{array}{l}\text { Huma } \\
\text { n-Scale }\end{array}$} & $\begin{array}{l}\text { Height-to- } \\
\text { width } \\
\text { /Distance } \\
\text { ratio }\end{array}$ & $\begin{array}{l}\text { Not within the } \\
\text { appropriate } \\
\text { ratio of } 1: 2 / 1: 3 \\
\text { when observing } \\
\text { from point A \& } \\
\text { B. Present } \\
\text { when observing } \\
\text { from point C. }\end{array}$ & High & $\begin{array}{l}\text { Not within the } \\
\text { appropriate } \\
\text { ratio of } 1: 2 / 1: 3 \\
\text { when observing } \\
\text { from all three } \\
\text { points }(A, B, C)\end{array}$ & High & $\begin{array}{l}\text { Not within the } \\
\text { appropriate ratio } \\
\text { of } 1: 2 / 1: 3 \text { when } \\
\text { observing from } \\
\text { all three points } \\
(A, B, C)\end{array}$ & High \\
\hline & $\begin{array}{l}\text { Adequate } \\
\text { walking space }\end{array}$ & $\begin{array}{l}\text { Wide approach } \\
\text { ways, stairways } \\
\text { and doorways } \\
\text { were present, } \\
\text { but no } \\
\text { pedestrian } \\
\text { ramps present. }\end{array}$ & High & $\begin{array}{l}\text { Wide approach } \\
\text { ways, } \\
\text { stairways, } \\
\text { doorways and } \\
\text { ramps were } \\
\text { present. }\end{array}$ & High & $\begin{array}{l}\text { Less wide } \\
\text { approach ways, } \\
\text { stairways, } \\
\text { doorways and } \\
\text { ramps were } \\
\text { present. }\end{array}$ & High \\
\hline & $\begin{array}{l}\text { Large } \\
\text { immediate } \\
\text { internal } \\
\text { building } \\
\text { volume }\end{array}$ & $\begin{array}{l}\text { Both Atriums } \\
\text { with multiple } \\
\text { height spaces } \\
\text { were present. }\end{array}$ & High & $\begin{array}{l}\text { Atriums were } \\
\text { not found but } \\
\text { multiple height } \\
\text { spaces were } \\
\text { present. }\end{array}$ & $\begin{array}{l}\text { Mode } \\
\text { rate }\end{array}$ & $\begin{array}{l}\text { No atriums nor } \\
\text { multiple height } \\
\text { spaces were } \\
\text { present. }\end{array}$ & High \\
\hline $\begin{array}{l}\text { Climat } \\
\text { e } \\
\text { Respo } \\
\text { nsiven } \\
\text { ess }\end{array}$ & $\begin{array}{l}\text { External } \\
\text { shading }\end{array}$ & $\begin{array}{l}\text { Canopies and } \\
\text { building } \\
\text { protrusions } \\
\text { were present. } \\
\text { Awnings and } \\
\text { tree shady } \\
\text { areas were not } \\
\text { present. }\end{array}$ & $\begin{array}{l}\text { Mode } \\
\text { rate }\end{array}$ & $\begin{array}{l}\text { Awnings and } \\
\text { canopies were } \\
\text { not found. } \\
\text { Building } \\
\text { protrusions and } \\
\text { tree shady } \\
\text { areas not } \\
\text { effective. }\end{array}$ & Low & $\begin{array}{l}\text { Canopies and } \\
\text { building } \\
\text { protrusions were } \\
\text { present. } \\
\text { Awnings not } \\
\text { present. Tree } \\
\text { shady areas } \\
\text { were not } \\
\text { effective. }\end{array}$ & $\begin{array}{l}\text { Mode } \\
\text { rate }\end{array}$ \\
\hline
\end{tabular}




\begin{tabular}{|c|c|c|c|c|c|c|c|}
\hline & $\begin{array}{l}\text { Good internal } \\
\text { air quality }\end{array}$ & $\begin{array}{l}\text { Cross breeze } \\
\text { was poor. } \\
\text { Mechanical } \\
\text { ventilation was } \\
\text { not provided. } \\
\text { Air quality was } \\
\text { not maintained. }\end{array}$ & Low & $\begin{array}{l}\text { Mechanical } \\
\text { ventilation was } \\
\text { provided. Air } \\
\text { quality was not } \\
\text { maintained }\end{array}$ & High & $\begin{array}{l}\text { Mechanical } \\
\text { ventilation was } \\
\text { provided. Air } \\
\text { quality was not } \\
\text { maintained }\end{array}$ & High \\
\hline \multirow[t]{6}{*}{$\begin{array}{l}\text { Richne } \\
\text { ss of } \\
\text { Experi } \\
\text { ence }\end{array}$} & $\begin{array}{l}\text { Façade } \\
\text { details, }\end{array}$ & $\begin{array}{l}\text { Vertical rhythm } \\
\text { maintained, } \\
\text { depth, colours, } \\
\text { textures, } \\
\text { detailing and } \\
\text { signage } \\
\text { accommodated }\end{array}$ & High & $\begin{array}{l}\text { Vertical rhythm } \\
\text { maintained, } \\
\text { depth, colours, } \\
\text { textures, } \\
\text { detailing and } \\
\text { signage } \\
\text { accommodated }\end{array}$ & High & $\begin{array}{l}\text { Vertical rhythm } \\
\text { maintained. } \\
\text { Textures not } \\
\text { found. Depth, } \\
\text { colours, detailing } \\
\text { and signage } \\
\text { accommodated }\end{array}$ & High \\
\hline & Seatability, & $\begin{array}{l}\text { Adequate } \\
\text { amount of } \\
\text { comfortable } \\
\text { seating was not } \\
\text { provided. }\end{array}$ & Low & $\begin{array}{l}\text { Adequate } \\
\text { amount of } \\
\text { comfortable } \\
\text { seating was } \\
\text { provided in } \\
\text { some spaces. }\end{array}$ & $\begin{array}{l}\text { Mode } \\
\text { rate }\end{array}$ & $\begin{array}{l}\text { Adequate } \\
\text { amount of } \\
\text { Comfortable } \\
\text { seating was } \\
\text { provided in } \\
\text { some spaces. }\end{array}$ & $\begin{array}{l}\text { Mode } \\
\text { rate }\end{array}$ \\
\hline & Lighting, & $\begin{array}{l}\text { Satisfactory } \\
\text { lighting was } \\
\text { provided. }\end{array}$ & High & $\begin{array}{l}\text { Satisfactory } \\
\text { lighting was } \\
\text { fair. }\end{array}$ & $\begin{array}{l}\text { Mode } \\
\text { rate }\end{array}$ & $\begin{array}{l}\text { Satisfactory } \\
\text { lighting was not } \\
\text { provided. }\end{array}$ & Low \\
\hline & $\begin{array}{l}\text { Internal } \\
\text { enclosure }\end{array}$ & $\begin{array}{l}\text { No floor and } \\
\text { ceiling pattern } \\
\text { seen. Wall } \\
\text { placement was } \\
\text { seen. }\end{array}$ & Low & $\begin{array}{l}\text { Floor and } \\
\text { ceiling pattern } \\
\text { and wall } \\
\text { placement } \\
\text { were seen. }\end{array}$ & $\begin{array}{l}\text { Mode } \\
\text { rate }\end{array}$ & $\begin{array}{l}\text { Floor and ceiling } \\
\text { pattern was } \\
\text { seen. Wall } \\
\text { placement was } \\
\text { satisfactory. }\end{array}$ & $\begin{array}{l}\text { Mode } \\
\text { rate }\end{array}$ \\
\hline & Materiality & $\begin{array}{l}\text { Appropriate } \\
\text { material usage } \\
\text { was seen. }\end{array}$ & High & $\begin{array}{l}\text { Appropriate } \\
\text { material usage } \\
\text { was seen. }\end{array}$ & High & $\begin{array}{l}\text { Appropriate } \\
\text { material usage } \\
\text { was seen. }\end{array}$ & High \\
\hline & $\begin{array}{l}\text { Signs, } \\
\text { effective } \\
\text { signs and } \\
\text { symbols }\end{array}$ & $\begin{array}{l}\text { Appropriate } \\
\text { signage size and } \\
\text { positioning } \\
\text { were seen }\end{array}$ & High & $\begin{array}{l}\text { Appropriatenes } \\
\text { s of signage size } \\
\text { and positioning } \\
\text { was less but } \\
\text { fair. }\end{array}$ & High & $\begin{array}{l}\text { Appropriate } \\
\text { signage size and } \\
\text { positioning were } \\
\text { seen. }\end{array}$ & High \\
\hline $\begin{array}{l}\text { Visual } \\
\text { perme } \\
\text { ability }\end{array}$ & $\begin{array}{l}\text { How well the } \\
\text { building or } \\
\text { the interior } \\
\text { space is } \\
\text { understanda } \\
\text { ble from the } \\
\text { outside. }\end{array}$ & $\begin{array}{l}\text { Both Visual } \\
\text { links from } \\
\text { exterior - } \\
\text { interior \& } \\
\text { exterior - } \\
\text { exterior were } \\
\text { strong. }\end{array}$ & High & $\begin{array}{l}\text { Both Visual } \\
\text { links from } \\
\text { exterior - } \\
\text { interior \& } \\
\text { exterior - } \\
\text { exterior were } \\
\text { strong. }\end{array}$ & High & $\begin{array}{l}\text { Both Visual links } \\
\text { from exterior - } \\
\text { interior \& } \\
\text { exterior - } \\
\text { exterior were } \\
\text { strong. }\end{array}$ & High \\
\hline
\end{tabular}

\section{Discussion}

This empirical study revealed the close association of physical attributes of responsive architecture and their contribution to perceive the ETS of public buildings. Accordingly, responsiveness and PP of ETS related to five physical attributes: Physical Permeability, Human Scale, Climatic Responsiveness, Richness of the Experience, and Visual Permeability are discussed below. 


\section{Physical Permeability}

ETS of public buildings used physical permeability to a moderate level in order to make entry thresholds architecturally responsive. ETS that have street edges which allow for good public movements contribute well for responsiveness. Green shady areas play a vital role in making this good public movement. Similarly, they were well perceived by people and it contributed to the current literature suggested by Clemente and Erwing (2013). However, irrespective of the responsiveness of punctuations, people perceived the ETS of public buildings in a very high manner.

\section{Human Scale}

ETS of public buildings used human scale to a moderate level in order to make the entry threshold architecturally responsive. Responsiveness of ETS for Height: Width ratio was poor, nevertheless, they were well perceived by people. Thereby, the study argued that Height: Width/distance ratio contribute less for PP of ETS. It explored that adequate walking spaces were provided in the ETS of public buildings and it contributed in a very high manner to perceive human scale of public buildings. Comfortable approach way consisting of, wide passageways, ramps, staircases and doorways contributed to this as suggested by Underhill (1999) and Ariess (2009). The immediate internal building volume was used in a very high manner to achieve human scale at MRNPT. However, MRICC and BMICH used it moderately. Nonetheless, people's perception on immediate internal building volume at BMICH and MRNPT was high and MRICC was moderate. It can be seen that the height of the immediate internal volume was the contributing factor that resulted in people perceiving the volume as satisfactory.

\section{Climatic Responsiveness}

ETS of public buildings used climatic responsiveness in a poor manner to make entry threshold architecturally responsive. External shading was moderately used at MRNPT and BMICH while MRICC used this in a poor manner. PP on this reflected the same. As suggested by Whyte (1980) and Jacobs (1993), shading devices such as awnings, canopies, building protrusions and tree shades improved climatic responsiveness. Indoor air quality was achieved at a very high manner at MRICC and BMICH. On the other hand, use of air quality to achieve climatic responsiveness was poor at MRNPT. PP also reflected the same.

\section{Richness of the Experience}

ETS of public buildings used richness of experience to a reasonable level to make entry threshold architecturally responsive. Facade detail was highly used at MRNPT, while MRICC and BMICH used it moderately. Nevertheless, PP on facade detail was very high at all three case studies. Use of texture and colour, breaking down of building mass, maintenance of vertical and horizontal rhythm, detailing and signage were contributing factors as suggested by Jacobs (1993). Seatability was moderate at MRICC and BMICH while MRNPT was poor. PP also reflected the same. It can be seen that providing adequate seating in all components of an ETS is important.

Lighting control was moderate at MRNPT, MRICC and BMICH. However, PP on lighting control for richness of experience was high, medium and low at MRNPT, MRICC and BMICH respectively. It can be seen that the control of lighting in all components of an ETS was important. Contribution of internal enclosure for richness of experience was moderate at all three case studies. People also perceived this as moderate at MRICC and BMICH, however, the rating was low at MRNPT. It can be seen, as suggested by Clemente and Erwing (2013), Cullen (1971) and Jacobs (1993); an effective placement of walls, presence of ceiling, floor patterns and special features would contribute to the richness of experience in an internal enclosure.

Use of materials contributed for high richness of experience, at MRNPT and BMICH, while it was moderate at MRICC. Nevertheless, people perceived that material usage contributed to achieving a high richness of experience. Therefore, an effective material combination at all components of ETS would contribute to the richness of experience (Clemente \& Ewing, 2013). 
Signs and symbols contributed for high richness of experience at MRNPT and BMICH, though moderate at MRICC. PP also reflected the same. Therefore, it can be concluded that affective signs placed at a suitable visual range contribute to high richness of experience.

\section{Visual Permeability}

MRICC and BMICH used their visibility in the context to achieve high visual permeability while MRNPT was moderate. PP on visibility to achieve visual permeability, in all three cases was high. It should be noted that visibility of all components of threshold spaces contribute to achieve high visual permeability.

By incorporating the above-mentioned physical attributes in an effective way, architectural responsiveness can be achieved with a perfect balance of place making and social identity. This creates a pleasant environment to enhance social interaction. All three cases affirm that ETS are holistically successful when it contains the attributes of architectural responsiveness, in a well-balanced and meaningful manner that enhances the surrounding into a pleasant environment. This in turn makes the public pay attention to the space while using it.

ETS of all three cases had had a positive impact on the users, through the strong responsiveness of architecture towards the public realm. Thus, reiterating the importance of effective and sensitive design strategies that need to be adopted to an ETS.

The entrance is the starting point of the built environment and its spatial experience. As the entrance is the foremost element experienced by the user, the physical parameters of an entrance should express visual and sensual meanings of the assigned function of the building. Failing to do so effectively, will result in the public not being inclined to engage in the assigned function of the building. This can be achieved by better understanding the user and how people in general perceive a space.

\section{Conclusion}

Findings of the study revealed that ETS of all three cases studied were poor, with physical attributes related to responsive architecture. Nevertheless, they were well perceived by people. Therefore the study argues that people perceive ETS of public buildings irrespective of the degree of architectural responsiveness of its physical attributes.

Height-width ratio related to physical attribute - human scale, contribute least to the PP of ETS of public buildings. Hence, there is a clear dissension between the theoretical base of one of the elements of architectural responsiveness with PP.

Physical attributes in ETS in response to climatic conditions and visual permeability have a relative impact on $\mathrm{PP}$.

Facade details, materials used, signs, symbols, etc. that contribute to the richness of the experience was also well perceivable to people. The usage of materials and textures were directing people towards the particular space which is commendable.

\section{Recommendations}

The threshold is only a part of the building. However, it can be seen that if the required ambience is thus achieved at this stage, the user will feel conditioned to participate in the specific function the building is designed for. Understanding and applying principles of architecture used to depict required ideals in buildings are important. This understanding helps architects to express the intended identity and sense of place, which ultimately leads to a functionally successful building. 


\section{Directions for further studies}

There are functional and categories of user dimensions to (public/private/semi-public) the study of threshold spaces in public buildings and its responsiveness towards users. While this study focused on public buildings and PP upon them; findings of this study could prompt further research of various other building categories (ex: entry thresholds of vertical developments, commercial facilities etc.)

For such studies, depending on the function and the user category, more components of architectural responsiveness could be added. Further studies can also be carried out to determine the degree to which PP is affected by previous experience, psychological needs of the users, personal preferences and cultural factors.

\section{References:}

Alakavuk, E. (2018) Threshold Approaches to Architectural Design Studio, Turkey: EDP Sciences.

Alexander, C. (1970) The Timeless Way of Building, 1st edn. New York: Oxford University Press. Alexander, C. (1977) A pattern language. California: Oxford University Press.

Bachelard, G. (1969) The poetics of space, 1st edn. Boston: Beacon Press

Bentley, I. (1985) Responive Environments, $10^{\text {th }}$ edn. London: Architectural Press.

Blumer, H. (1969) 1986 Symbolic Interactionsim: Perspective and Method. s.l: University of California Press.

Broadbent, G. (1996) A Plain Man's Guide to the Theory of Signs in Architecture, in: K. Nesbitt, edn. Carr, S., Rivlin, L. \& Stone, A., (1993) Public Space. Cambridge: Cambridge University Press.

Ching, D. (1995) Visual Dictionary of Architecture. Canada: John Wiley and Sons.

Ching, F. D. (2010) Architecture: Form, Space, \& Order. $3^{\text {rd }}$ edn. New Jersey: John Wiley \& Sons Inc.

Ching, F. D. (2015) Form, Space and Order, Fourth Edition. $3^{\text {rd }}$ edn. Hoboken, New Jersey: John Wiley and

Clemente, O. \& Erwing, R. (2013) Measuring Urban Design: Metrics for Livable Spaces. Washington: Island Press.

Corbusier, L. (1986) Towards a New Architecture. New York: Dover Publications.

Cullen, G. (1971) The Concise Townscape by Gordon Cullen. London: Butterworth-Heinemann.

Dee, L. (2018) Against Art and Culture. $1^{\text {st }}$ edn. s.l.: Palgrave Macmillan.

Gehl, J. (2010) Cities for People. Washington, DC: Island Press.

George, S. (1999) Architectural Theories of Design. Quezon: JMC Press.

Haesler, O. (1981) Color in Townscape. $1^{\text {st }}$ edn. Great Britain: W H Freeman \& Co.

Hertsberger, H., (2005) Lessons for students in Architecture. $5^{\text {th }}$ edn. Germany: 010 Publishers.

Hiller, J. \& Hansen, B. (1989) The Social Logic of Space. London: Cambridge University Press. Jacobs, A. (1993) Great Streets. Cambridge: MIT Press.

Joedicke, J. (1985) Space and form in Architecture. s.l.: Krämer, Stuttgart.

Kaplan, R. K., The Experience of Nature. $1^{\text {st }}$ edn. 1989. New York: Cambridge University Press.

Kamrani, A. \& Behzadfar, M. (2016) The Meaning of Place, A Constant or Changing Quality? Lynch, Rapoport and Semiotics View Points. Space Ontology International Journal, 5(2), pp. $43-47$

Lynch, K. (1960) The Image of the City. USA: MIT Press.

Lynch, K. (1981) A Theory of Good City Form. s.l.: MIT Press.

Langer, S. (1966) The Cultural Importance of Arts. The Journal of Aesthetic Education, Volume 1 , pp. 5-12

Elements of Art/Design and Principles of Design. Viewed on 10 January 2019, http://flyeschool.com/content/elements-artdesign-and-principles-designorganization

GharPedia, (2018) Importance of rhythm in Architecture. Viewed on 6 March 2019,

https://gharpedia.com/rhythm-in-architecture/ 